\title{
Transradial Coronary Intervention in Chronic Total Occlusion in a Patient With Mirror Image Dextrocardia
}

\author{
Anupam Bhambhani ${ }^{1}$, Amey Joshi ${ }^{1}$ \\ 1. Cardiology, Vydehi Institute of Medical Sciences and Research Centre, Bangalore, IND
}

Corresponding author: Anupam Bhambhani, anupam.bhambhani@yahoo.in

\begin{abstract}
Dextrocardia poses challenges in the percutaneous coronary intervention, particularly through radial access. The presence of chronic total occlusion further adds to the technical difficulties in such cases due to unfamiliar orientations of the coronary arteries, guide catheter instability, and problems in advancing the hardware across the occluded lesions.
\end{abstract}

We report here a successful percutaneous intervention in a chronic total occlusion of the left anterior descending coronary artery, done through right radial access in a patient with situs-inversus and dextrocardia.

The trans-radial percutaneous intervention approach is safe and feasible in patients with dextrocardia. Preplanned imaging strategies and the choice of appropriate hardware tremendously help in successfully completing the intervention in such cases.

Review began 03/09/2021 Review ended 03/17/2021 Published 03/19/2021

๑) Copyright 2021

Bhambhani et al. This is an open access article distributed under the terms of the Creative Commons Attribution License CC-BY 4.0, which permits unrestricted use, distribution, and reproduction in any medium, provided the original author and source are credited.
Categories: Cardiology

Keywords: dextrocardia, percutaneous coronary intervention, radial access, chronic total occlusion, situs-inversustotalis

\section{Introduction}

Percutaneous coronary intervention (PCI) through trans-radial access (TRA) is favored by the interventional cardiologists across the globe, but the presence of situs-inversus-totalis makes it challenging, mainly due to the difficulties encountered in achieving co-axial positioning of the guide catheters. Right TRA further alters the catheter course at the subclavian artery take-off from the aortic arch because of the unusual angular relationship between the two vessels.

We report here a successful PCI in chronic total occlusion (CTO) of the left anterior descending (LAD) coronary artery, done through right TRA, in a patient with situs-inversus and dextrocardia.

\section{Case Presentation}

A 59-year-old gentleman, a known case of mirror-image dextrocardia, presented with chronic stable angina that was partially responsive to medical therapy. The pain was retro-sternal and radiated to the right shoulder. There were no conventional risk factors for ischemic heart disease. A 12-lead electrocardiogram was consistent with dextrocardia and was otherwise unremarkable. Coronary angiography was done through the right radial access using 5F TIG- Optitorque ${ }^{\circledR}$ catheter (Terumo-interventional-systems, Tokyo, Japan). It demonstrated a 100\% stenosis in the mid-segment of LAD with Rentrop grade 2 collaterals (Figures $1 A, 1 B$, $2 A$, Video 1). There was no significant stenosis in other coronary arteries. 


\section{Cureus}

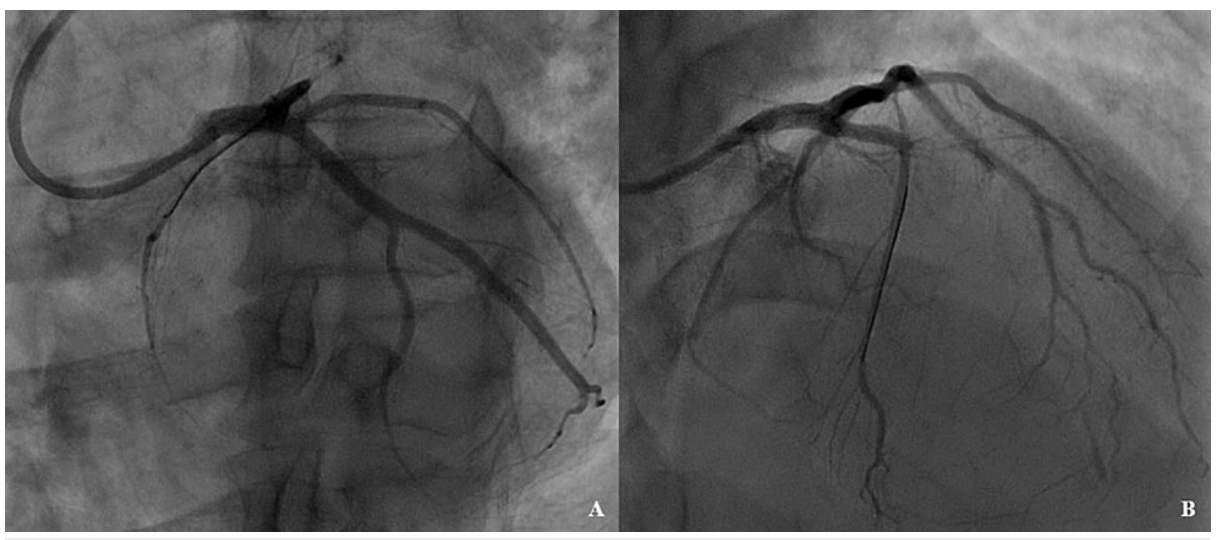

FIGURE 1: Left coronary angiograms obtained after applying digital leftright image inversion, while the camera was positioned at horizontally reverse angles (double inversion). (A) Caudally tilted right anterior oblique image resembling conventional spider view. (B) Cranially tilted left anterior oblique image resembling conventional right anterior oblique view. Guidewire in septal artery, serving as anchor, can be seen in both these pictures.

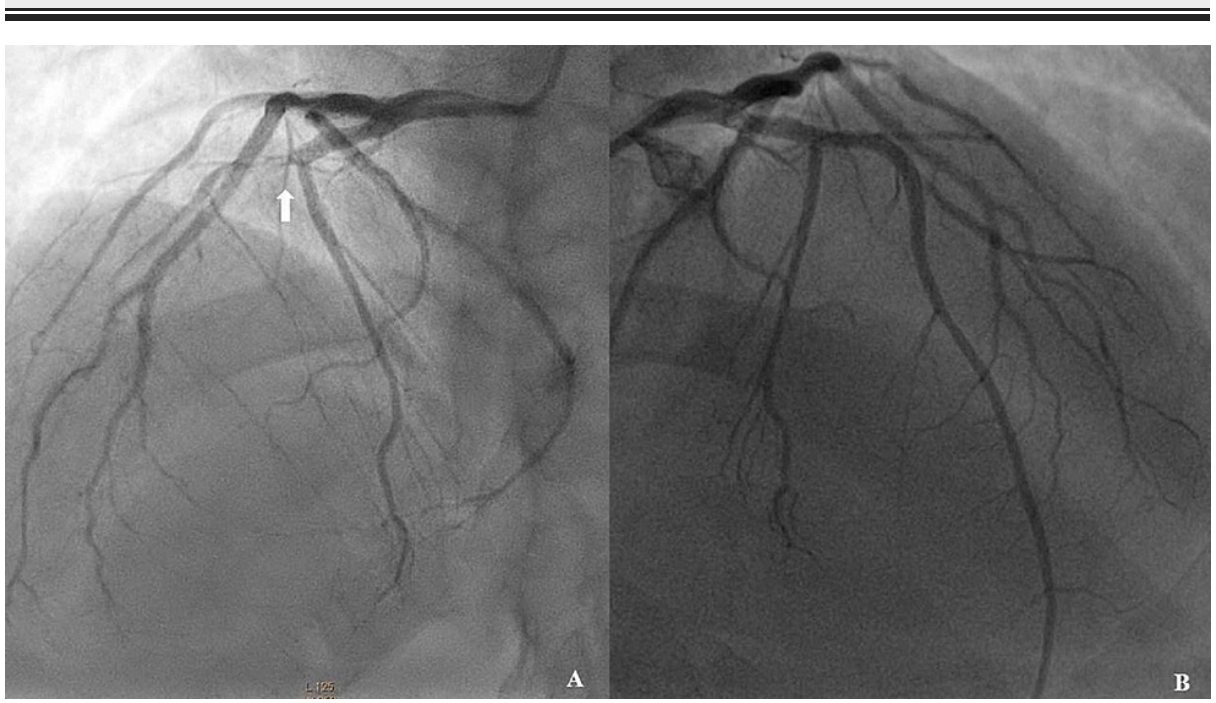

FIGURE 2: Left coronary angiograms before (A) and after (B) the intervention (arrow is pointing at the chronic total occlusion in left anterior descending artery).

VIDEO 1: Left coronary angiogram showing $100 \%$ stenosis in LAD with Rentrop grade 2 collaterals.

LAD - left anterior descending

View video here: https://vimeo.com/519793998

We decided to perform PCI to LAD through right radial access. Cannulation of the left coronary artery (LCA), situated on the right side in this case, was attempted using a $6 \mathrm{~F} 3.5$ curve Extra-backup coronary guidecatheter (Medtronic Launcher, Santa Rosa, CA, USA) by maneuvering it with counter directional rotations, i.e. wherever clockwise rotation works in normal situs, the counter-clock rotation was performed and vice versa. This method failed to position the catheter selectively into the coronary ostium. In order to achieve selective LCA cannulation, the catheter was advanced into the respective sinus with counter-clock rotation and then was pushed up from the aortic root with simultaneous clockwise rotation. This maneuver 


\section{VIDEO 2: Non-selective cannulation of left coronary artery.}

View video here: https://vimeo.com/519793965

Following this, a 0.14 inch-180 cm Sion Blue (ASAHI-INTECC, USA) guidewire was advanced into the septal artery and used as an anchor, over which the catheter could be advanced to a desirable coaxial position into the LCA ostium (Video 3).

\section{VIDEO 3: Selective cannulation of coronary artery achieved with the help of anchor wire in septal branch of left anterior descending artery.}

View video here: https://vimeo.com/519793934

In order to make the CTO anatomy clearer and to achieve vessel orientation closer to normal, we acquired further images with right-left image inversion on the screen (by digitally activating horizontal reverse sweep on the console) and, at the same time, reversed the horizontal angles of image-intensifier (camera) position, while maintaining the conventional cranial-caudal angles. In this way, the camera position in caudally tilted right-anterior-oblique (RAO) angle provided coronary image resembling spider view (Figure 1A), while in cranially tilted left-anterior-oblique angle, it provided coronary image resembling routine RAO-cranial view (Figure 1B). By practicing this double inversion technique, angiographic images resembling normal situs were obtained.

After adequate imaging, crossing of the CTO was attempted using another 0.014 inch- $180 \mathrm{~cm}$ Sion Blue wire. The initial failure of this wire necessitated the support of a $1.25 \times 6 \mathrm{~mm}$ semi-compliant balloon, using which the proximal cap of the CTO could be penetrated (Video 4).

\section{VIDEO 4: Penetrating proximal cap of the chronic total occlusion while stabilizing the guide catheter with help of anchor wire in the septal branch of left anterior descending artery.}

View video here: https://vimeo.com/519793899

While traversing the CTO body, the wire entered a large diagonal branch; leaving this wire in the diagonal branch, we retracted the first wire that was stationed in the septal branch as an anchor and advanced it into the distal LAD. During this, the wire in the diagonal branch served as an anchor for guide-catheter stability and at the same time guided us to the distal LAD like a parallel wire (Video 5).

\section{VIDEO 5: Occlusion crossed while maintaining anchor in the diagonal branch of Left Anterior Descending artery.}

View video here: https://vimeo.com/519793863

After serial pre-dilatations with 1.25 and $2.5 \mathrm{~mm}$ diameter semi-compliant balloons, a $2.75 \times 16 \mathrm{~mm}$ Everolimus eluting stent was deployed across the lesion at $12 \mathrm{~atm}$ pressure. A final angiogram revealed a well-deployed stent with TIMI-III flow and no residual dissection (Figure $2 B$ ). The recovery was uneventful and the patient is free of angina at 15 months' follow-up.

\section{Discussion}

Dextrocardia poses challenges in the diagnosis as well as invasive treatment of coronary artery disease due to several factors including unusual site of anginal pain on the right side, altered QRS morphology resulting from a reverse sequence of ventricular depolarisation, unfamiliar orientations of the coronary artery branches, and technical difficulties encountered during the intervention.

Trans-radial PCI in patients with situs-inversus and dextrocardia is technically demanding due to difficulties encountered in achieving the coaxial position of conventional guide catheters. Right TRA further alters the catheter course at the subclavian artery take-off from the aortic arch, as the angular relationship between the two vessels is a mirror image of what is expected in situs-solitus. The presence of СТO in such cases adds to the complexity of the intervention due to difficulties envisaged in the angiographic assessment of the 
anatomy of the occluded segment, assessment of collateral channels, and in hardware advancement across the СТО, particularly with suboptimal catheter stability.

In order to review the techniques used by other operators in successfully performing PCI through TRA in the presence of mirror-image dextrocardia, we searched the databases of PubMed, PubMed Central, Google Scholar, and Cochrane for similar case reports. A total of 11 publications [1-11] were identified (Table 1), reporting PCI on 17 lesions in 13 patients.

\begin{tabular}{|c|c|c|c|c|c|c|c|c|c|c|}
\hline \multirow{2}{*}{$\begin{array}{r}\text { S } \\
\text { no. }\end{array}$} & \multirow{2}{*}{ Reference } & \multirow{2}{*}{$\begin{array}{l}\text { Clinical } \\
\text { presentation and } \\
\text { duration of } \\
\text { symptoms }\end{array}$} & \multirow[b]{2}{*}{$\begin{array}{l}\text { Vascular } \\
\text { Access }\end{array}$} & \multirow{2}{*}{$\begin{array}{l}\text { PTCA } \\
\text { guidewire } \\
\text { used }\end{array}$} & \multirow{2}{*}{$\begin{array}{l}\text { Culprit artery } \\
\text { and severity of } \\
\text { stenosis }\end{array}$} & \multicolumn{2}{|c|}{ Diagnostic or guide catheter } & \multirow{2}{*}{$\begin{array}{l}\text { Left-Right } \\
\text { screen image } \\
\text { inversion } \\
\text { technique }\end{array}$} & \multirow{2}{*}{$\begin{array}{l}\text { Left-Right } \\
\text { reversal of } \\
\text { camera } \\
\text { positioning }\end{array}$} & \multirow{2}{*}{$\begin{array}{l}\text { Special } \\
\text { adjuvant } \\
\text { technique }\end{array}$} \\
\hline & & & & & & $\begin{array}{l}\text { Irled and } \\
\text { failed }\end{array}$ & Successfully used & & & \\
\hline 1 & $\begin{array}{l}\text { Macdonald } \\
\text { et al., } 2007 \\
\text { [1] }\end{array}$ & $\begin{array}{l}\text { Stable ischemic } \\
\text { heart disease; >1 } \\
\text { month }\end{array}$ & $\begin{array}{l}\text { Right } \\
\text { TRA }\end{array}$ & $\begin{array}{l}\text { Traverse } \\
\text { wire }\end{array}$ & $\begin{array}{l}\text { Mid-segment } \\
\text { LAD 100\% }\end{array}$ & $\begin{array}{l}\text { Judkin's Left } \\
4 \text { and } 5 \\
\text { curves }\end{array}$ & Extra-backup (EBU) 3.5 & Not applied & Applied & $\begin{array}{l}\text { Balloon } \\
\text { support }\end{array}$ \\
\hline 2 & $\begin{array}{l}\text { Zhao et al., } \\
2010 \text { [2] }\end{array}$ & $\begin{array}{l}\text { Acute coronary } \\
\text { syndrome 1-day }\end{array}$ & $\begin{array}{l}\text { Right } \\
\text { TRA }\end{array}$ & Not reported & $\begin{array}{l}\text { Proximal RCA } \\
80 \% \\
\text { Mid-segment } \\
\text { LCX } 85 \%\end{array}$ & None & 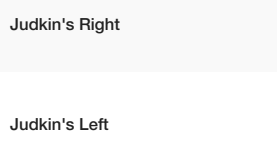 & Not applied & Not applied & None \\
\hline 3 & $\begin{array}{l}\text { Ishiguro et } \\
\text { al., } 2011 \text { [3] }\end{array}$ & $\begin{array}{l}\text { Acute coronary } \\
\text { syndrome 2-weeks }\end{array}$ & $\begin{array}{l}\text { Right } \\
\text { TRA }\end{array}$ & $\begin{array}{l}\text { Runthrough, } \\
\text { Grandslam } \\
\text { guidewire }\end{array}$ & $\begin{array}{l}\text { Ostial RCA } \\
\text { Critical } \\
\text { stenosis }\end{array}$ & $\begin{array}{l}\text { Judkin's } \\
\text { Left-4 }\end{array}$ & $\begin{array}{l}\text { Diagnostic - heat modified } \\
\text { Judkin's Right-4; Guide catheter - } \\
\text { Ikari Left } 3.0\end{array}$ & Not applied & Not applied & $\begin{array}{l}\text { Parallel } \\
\text { wire }\end{array}$ \\
\hline \multirow{3}{*}{4} & $\begin{array}{l}\text { Menozzi et } \\
\text { al. } 2012[4]\end{array}$ & & & & & & & & & \\
\hline & Case 1 & $\begin{array}{l}\text { Non-ST elevation } \\
\text { myocardial } \\
\text { infarction; 48-hours }\end{array}$ & $\begin{array}{l}\text { Right } \\
\text { TRA }\end{array}$ & BMW & $\begin{array}{l}\text { Ostial LAD } \\
100 \%\end{array}$ & $\begin{array}{l}\text { Optitorque }{ }^{\circ} \\
\text { TIGER }\end{array}$ & Extra-backup (EBU) 3.5 & Not applied & Applied & None \\
\hline & Case 2 & $\begin{array}{l}\text { ST-elevation } \\
\text { myocardial } \\
\text { infarction }\end{array}$ & $\begin{array}{l}\text { Right } \\
\text { TRA }\end{array}$ & BMW & $\begin{array}{l}\text { Distal RCA } \\
\text { critical } \\
\text { stenosis }\end{array}$ & None & Judkin's Right 4.0 & Not applied & Applied & None \\
\hline 5 & $\begin{array}{l}\text { Showkathalli } \\
\text { et al., } 2012 \\
\text { [5] }\end{array}$ & $\begin{array}{l}\text { myocardial } \\
\text { infarction; } \\
\text { (facilitated PCI) }\end{array}$ & $\begin{array}{l}\text { Right } \\
\text { TRA }\end{array}$ & Not reported & $\begin{array}{l}\text { Mid and distal } \\
\text { RCA calcific } \\
\text { stenosis }\end{array}$ & None & Amplatz Right-2 guide catheter & Not applied & Not applied & $\begin{array}{l}\text { Rotational } \\
\text { atherectomy }\end{array}$ \\
\hline 6 & $\begin{array}{l}\text { Goel and } \\
\text { Moorthy, } \\
2013[6]\end{array}$ & $\begin{array}{l}\text { ST-elevation } \\
\text { myocardial } \\
\text { infarction; 4-hours }\end{array}$ & $\begin{array}{l}\text { Right } \\
\text { TRA }\end{array}$ & BMW & Mid RCA 99\% & None & ECR $\circledast$ guide catheter & Applied & Applied & None \\
\hline \multirow[b]{2}{*}{7} & & & & BMW & $\begin{array}{l}\text { Mid-segment } \\
\text { RCA 99\% }\end{array}$ & None & Judkins Right- 4 guide catheter & Not applied & Applied & None \\
\hline & 2015 [7] & two-days & TRA & BMW & $\begin{array}{l}\text { Proximal LCX } \\
80 \%\end{array}$ & $\begin{array}{l}\text { Optitorque }{ }^{8} \\
\text { TIGER, } \\
\text { Judkins } \\
\text { Left-4 }\end{array}$ & Amplatz Left-2 guide catheter & Not applied & Applied & None \\
\hline 8 & $\begin{array}{l}\text { Michas et } \\
\text { al., } 2016 \text { [8] }\end{array}$ & $\begin{array}{l}\text { ST-elevation } \\
\text { myocardial } \\
\text { infarction; 30- } \\
\text { minutes }\end{array}$ & $\begin{array}{l}\text { Right } \\
\text { TRA }\end{array}$ & BMW & $\begin{array}{l}\text { Postero-lateral } \\
\text { branch of RCA } \\
99 \%\end{array}$ & None & Judkins Right & Not applied & Applied & \\
\hline \multirow{3}{*}{9} & & & & & $\begin{array}{l}\text { Proximal RCA } \\
80 \%\end{array}$ & $\begin{array}{l}\text { Judkin's } \\
\text { Right-4 } \\
\text { guide } \\
\text { catheter }\end{array}$ & Extra-backup (EBU) 3.0 & \multirow{3}{*}{ Not applied } & \multirow{3}{*}{ Applied } & \\
\hline & $\begin{array}{l}\text { Potdar et al., } \\
2016 \text { [9] }\end{array}$ & $\begin{array}{l}\text { Unstable angina; 5- } \\
\text { days }\end{array}$ & $\begin{array}{l}\text { Right } \\
\text { TRA }\end{array}$ & $\begin{array}{l}\text { Whisper MS } \\
\text { guide wire }\end{array}$ & $\begin{array}{l}\text { Mid-segment } \\
\text { LAD } 80 \%\end{array}$ & None & Extra-backup (EBU) 3.0 & & & \\
\hline & & & & & $\begin{array}{l}\text { Proximal } \\
\text { segment LCX }\end{array}$ & None & Extra-backup (EBU) 3.0 & & & \\
\hline
\end{tabular}




\section{Cureus}

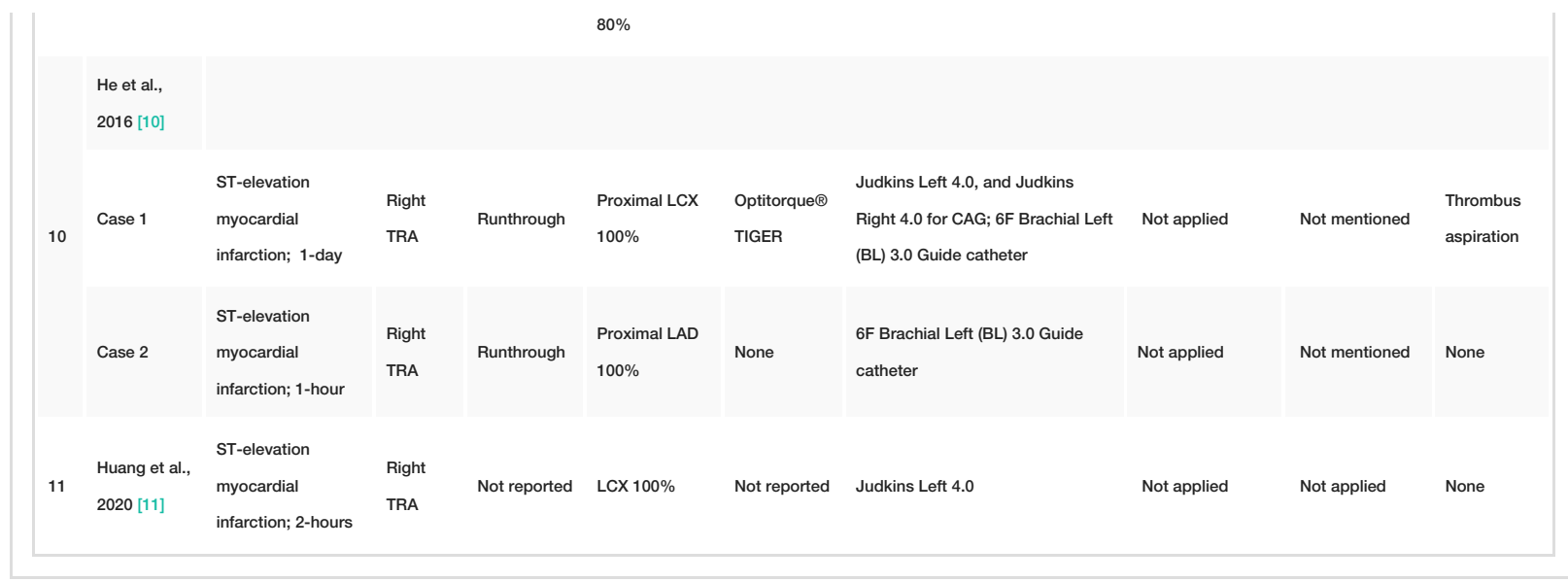

TABLE 1: Technical details in reported cases of trans-radial coronary interventions in patients with situs-inversus and dextrocardia.

TRA, transradial access; LAD, left anterior descending; RCA, right coronary artery; LCx, left circumflex

Five successful PCIs were reported on occluded vessels $[1,4,10,11]$. Four of these interventions were done on acute occlusions of $\leqslant 24$-hour duration $[4,10,11]$, while in the remaining one, the clinical diagnosis was stable ischemic heart disease (IHD), the authors did not specify if the lesion was a CTO [1].

The earliest case of successful trans-radial PCI in dextrocardia was described by Macdonald et al. in 2004 [1]. Goel and Moorthy were the first to describe the usefulness of the double image inversion technique in dextrocardia [6], which we also used in our case. Although no other operator reported use of the double inversion, six operators described the ease of doing PCI by horizontally reversed positioning of the camera $[1,4,6-9]$ and in one report [10], the imaging details were not mentioned. Back-up support catheters were preferred in all cases and EBU catheter, with counter direction rotations, successfully cannulated LCA in most cases. As seen in Table 1, hydrophilic-coated guidewires were preferred by most operators; however, hydrophobic wire with balloon support was used in one case [1].

Based on our and other operators' experiences, we found the following technical steps helpful in successfully completing CTO PCI through TRA in dextrocardia patients: (a) double inversion modification while imaging, i.e. use of right-left image inversion in combination with camera positioning at horizontally opposite angles, substantially improves the ease of angiographic interpretation; (b) back-up catheters should always be preferred; in case of encountering difficulty in coaxial catheter positioning, support techniques (e.g. wire anchor or balloon anchor) should be employed instead of switching to catheters with a sub-optimal back-up; (c) counter directional rotation of catheters is instrumental in cannulation of coronary ostia; (d) extension catheters like Guideliner ${ }^{\mathrm{TM}}$ or Guidezilla ${ }^{\mathrm{TM}}$ may provide extra support if needed; (e) lubricious wires with soft tips are good for approaching the proximal cap, but need balloon or microcatheter support for penetrating and traversing the CTO.

\section{Conclusions}

Right transradial access for PCI in dextrocardia is safe and practical. The knowledge of the atypical presentation of angina pectoris and other difficulties associated with the diagnosis of IHD in dextrocardia patients may help in the early identification and management of the disease. Pre-planned imaging strategies and appropriate choice of hardware tremendously help in successfully completing PCI in such cases.

\section{Additional Information \\ Disclosures}

Human subjects: Consent was obtained or waived by all participants in this study. Conflicts of interest: In compliance with the ICMJE uniform disclosure form, all authors declare the following: Payment/services info: All authors have declared that no financial support was received from any organization for the submitted work. Financial relationships: All authors have declared that they have no financial relationships at present or within the previous three years with any organizations that might have an interest in the submitted work. Other relationships: All authors have declared that there are no other relationships or activities that could appear to have influenced the submitted work.

\section{References}


1. Macdonald JE, Gardiner R, Chauhan A: Coronary angioplasty via the radial approach in an individual with dextrocardia. Int J Cardiol. 2008, 131:10-1. 10.1016/j.ijcard.2007.07.035

2. Zhao ZW, Lin CG, Chen LL: Repeat right transradial intervention in 9 days in a patient with dextrocardia and situs inversus. Tex Heart Inst J. 2010, 37:734-5.

3. Ishiguro H, Murohara T, Ikari Y: The feasibility of using Ikari left catheter via the right radial approach in a patient with dextrocardia for better guiding support. J Invasive Cardiol. 2011, 23:288-90.

4. Menozzi M, Guiducci V, Pignatelli G, Giacometti P, Manari A: Coronary stenting using the radial approach in two women with situs viscerum inversus and acute myocardial infarction. Cardiovasc Revasc Med. 2012, 13:128-32. 10.1016/j.carrev.2010.06.006

5. Showkathali R, Davies JR: Transradial rotablation in a patient with dextrocardia and acute ST-elevation myocardial infarction. IntervMed Appl Sci. 2012, 4:221-3. 10.1556/IMAS.4.2012.4.8

6. Goel PK, Moorthy N: Trans-radial primary percutaneous coronary intervention in dextrocardia using double inversion technique. J Cardiol Cases. 2013, 8:31-3. 10.1016/j.jccase.2013.03.010

7. Sinha RP, Agarwal D, Sarang AM, Thakkar AS: Successful transradial percutaneous coronary intervention in a patient with dextrocardia and situs inversus. J Clin Diagn Res. 2015, 9:04-6.

10.7860/JCDR/2015/10622.5412

8. Michas G, Kaplanis I, Stougiannos P, Arapi S, Sergi E, Gavrielatos G, Trikas A: Successful transradial coronary angioplasty in a patient with dextrocardia and acute myocardial infarction. Hellenic J Cardiol. 2016, 57:463-6. 10.1016/j.hjc.2016.11.020

9. Potdar A, Sapkal G, Sharma S: Triple vessel percutaneous coronary intervention in a patient with situs inversus dextrocardia using a transradial approach. Indian Heart J. 2016, 68:32-5. 10.1016/j.ihj.2016.03.005

10. He J, Sun Y, Zhang X, et al.: Emergent percutaneous coronary intervention for acute myocardial infarction in patients with mirror dextrocardia: case reports and brief review. Cardiovasc Diagn Ther. 2016, 6:267-73. 10.21037/cdt.2015.12.12

11. Huang Y, Zhou H, Wu L: Acute total occlusion of left circumflex artery in a patient with dextrocardia and situs inversus. J Int Med Res. 2020, 48:300060519893180. 10.1177/0300060519893180 